UDC 1(091):316

Hovhannes HOVHANNISYAN

\title{
IDEA AND MODELS OF CIVIL SOCIETY: DEVELOPMENT TENDENCIES, ARGUMENTS PRO AND CON
}

\begin{abstract}
The article presents the main stages of development and major modifications of the idea of civil society from Greek and Roman antique philosophy to modern researchers. It discusses two broad (philosophical) and narrow (the third sector of organizing civil society) - perceptions of civil society and proposes corresponding definitions. Etatistic (controlled), liberal, conflicting, partnership, segmentational and linked models of civil society are analyzed. The expediency of linked and partnership models is substantiated from the position of security and harmonious development of the civic society.
\end{abstract}

Keywords: civil society; civil society organizations; civil system security; etatistic, liberal, conflicting, partnership, segmentational and linked models of civil society.

In the course of global history various concepts have been shaped of how best of all to organize the society, the desirable future. While religion promises the best life in extramundane world, variable political and philosophical schools and doctrines have tried to imagine and shape that best life conditioned by effective organization of social relations in actual reality.

Among these dreams could be Plato's ideal state, Th.More's «Utopia», T.Campanella's «The City of the Sun», K.H.SaintSimon's, F.Ch. Foureier's utopian views, Marxist ideas about communism and others. The most viable and realistic among all these dreams and programs, perhaps, appeared to be the idea of civic society.

The idea of civic society, similar to that of democracy, is not a dogma. It has modified and undergone amendments in the course of history of global thought and practice, thus being edited, rectified and developed.

In modern times, too, the future of democracy is mainly linked to the idea of civic society. Resolution of several issues typical of the current stage of development of democratic systems is concomitant to the development of the civic society. And the latter supposes methodologically substantial study of the idea of civil society, of its components, of its structural and functional features, of possible ways of development and models, and also the existence of their realistic elaboration.

Although in professional literature the formation of the idea of civic society is more often connected with the era of Enlightenment and Enlightenment philosophy, it should be noted that it dates back to the roots of ancient Greek and Roman philosophy.

One may come across the notions Poli- 
tike Koinonia ${ }^{1}$ and Societas Civilis (Cicero, "De Republica," XXXII, 49; "Civil Society: history and possibilities", 2011, p. 33) ${ }^{2}$ in the works of ancient Greek and Roman thinkers.

Within the ancient Greek civilization the notions of city and state were objectively synonymous. Citizenship was interpreted as the reality of being a full member of a given society, of having regulated relations with government structures, of enjoying rights and responsibilities. The perception of a civic or political society was that of a public where the core role in organizational and governmental processes was allocated to state institutions.

Somewhat similar understanding of the civil society is also characteristic of the 17$18^{\text {th }}$ centuries Enlighteners. The English philosopher of the $17^{\text {th }}$ century Th. Hobbes, in line with other theorists of the public alliance (B.Spinoza, J.Locke, CH.Montesquieu), divided the social history into two stages: natural (or pre-political, pre-civic) and civic (or political). The natural state is characterized by the absence of state as the core institution regulating and administering public life. During that phase people interacted not as member-

1 “... this is that which is called in the State and the Political-Association". (Aristotle, 1877, p. 107. Jean L. Cohen and Andrew Arato, 1994, pp. 84-85)

2 The term was introduced by M.T.Cicero: “... quare cum lex sit civilis societatis vinculum, ius autem legis aequale, quo iure societas civium teneri potest, cum par non sit condicio civium? si enim pecunias aequari non placet, si ingenia omnium paria esse non possunt, iura certe paria debent esse eorum inter se qui sunt cives in eadem re publica. quid est enim civitas nisi iuris societas civium?". citizens of the same given society but as biological individuals ("A man is a wolf to another man") (Hobbes, 1998, p. 3). Unregulated freedom, the desire to possess and own, competition and distrust towards one other gave rise to "war of all against all" (Hobbes, 1991, pp. 94-96).

Constant dangers and insecurity forced people to unite and create a structure of common safety - the state. People gave up some of their natural rights and empowered the state with them, thus in return receiving guarantees to enjoy the other rights freely and without restraints. This is how they acquired a new status - that of a citizen. Civil status and citizens' society are the most civilized and warranted form of lifestyle and exercise of rights (Ibid, pp. 129-133).

The idea of civic society underwent further modifications and improvements within both Enlightenment and post-Enlightenment philosophical theory. The idea of monarchic rule was replaced by the ideas of power sharing between the legislative, executive and judicial branches, of creating the principle of checking and balancing them, which would grant citizens more opportunities to exercise and protect their rights.

$19^{\text {th }}$ century mass movements and political processes introduced some new alterations into the ideas about civil society actors and institutional constituents. This was an era when, as French sociologist and psychologist G. Le Bon described it, the right of monarchs was replaced by the right of masses, the time

3 "Homo homini lupus est". Thomas Hobbes uses this famous expression from the comedy "Asinaria by ancient Roman playwright Titus Plautus to describe the pre-political stage of social history. 
of heroes was replaced by the "era of crowds" (Le Bon, 2005, pp. 5-8) and the era of political parties to organize and direct these crowds. The latter assumed the functions of balancing and counterbalancing in relations with the state; of integrating citizens' interests and submitting them at the level of political decision-making. Thus, the modern understanding of "government" and "opposition" poles emerged.

In the modern stage of evolution of notions about civil society, Alexis de Tocqueville's and G. Hegel's ideas regarding the significance of decentralization and autonomy in the processes of public administration had a huge influence (Hegel, 1991, pp. 219-226; Tocqueville, $1848^{\mathrm{a}}$, pp. 42-94; Tocqueville, $1848^{\mathrm{b}}$, pp. 35-53).

In the $20^{\text {th }}$ century the role of non-governmental (non-political), non-profit organization - "the third sector" - in the social life became increasingly signified. Currently these organizations are entrusted with a special role to integrate citizens' interest, to aggregate, articulate and voice them; to represent them in relations with parties and government structures. In public administration processes they conduct organizational, regulating-integrating, propagating, monitoring and several other core functions.

In modern understanding of the civil society, besides government structures and political parties, a vital mission in the processes of organizing and governing the public life is fulfilled also by non-government organizations formed on voluntary basis and common interests and functioning on the principle of autonomy. (See Diagram 1.) In the broader sense not only formal non-governmental organizations, their networks and associations but also movements, interest groups and mass media should be observed within the third sector.

\section{Diagram 1. The Basic Components of Civil Society}

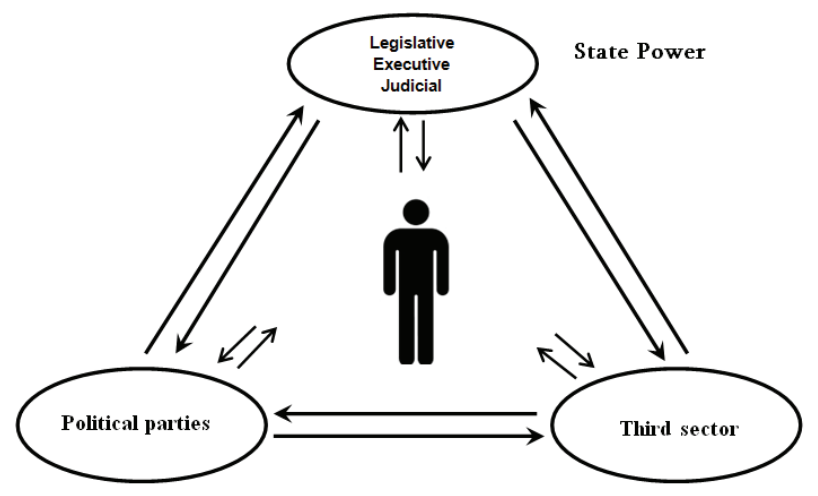

In various stages of development of universal mind, despite certain variations in descriptions of the civil society, there has been one common ideological-methodological fabric for them: the idea of the citizen as the central value of the social system possessing certain interests and inalienable rights (see Hovhannisyan, 2005, pp. 24-25).

Two definitions of the civic society can be, thus, proposed. 
In the broader, philosophical sense, the civic society is a mode of organizing and governing public life where the individualcitizen is the core value, the main functioning subject and final end with his/her interests, requirements and rights.

This perception observes all the civil society institutions demonstrated in the diagram above.

In the narrower sense, highlighting the role of non-governmental organizations in the processes of organizing and governing public life, the third sector is meant by civil society; that is non-governmental, non-profit organizations, foundations, associations of legal persons, artistic unions, charity organizations, civil movements and other forms of activism.

Thereby, within a democracy the civic society is a mode of organizing public life characterized by: 1) a wide network of nongovernmental structures formed voluntarily (unions, associations, organizations); 2) a comprehensive system comprising economic, political, social, spiritual, cultural relations.

The second definition is more widespread and involved in the documents of international organizations ("CIVICUS Civil Society Index. Armenian Civil Society..." 2010, p. 14) ${ }^{4}$.

4 The World Bank has adopted a definition of civil society developed by a number of leading research centers: "the term civil society is to refer to a wide array of non-governmental and not-for-profit organizations that have presence in public life, expressing the interests and values of their members or others, ... involve a wide array of organizations: community groups, non-governmental organizations (NGOs), labor unions, indigenous groups, charitable or-
A number of possible models of the civil society can be identified regarding relations between non-governmental organizations and the state, and non-governmental organizations and political parties.

On the basis of relations between nongovernmental organizations and state departments etatistic ${ }^{5}$ (controlled), liberal (sometimes conflicting) and partnership models can be singled out.

In case of the first model non-governmental organizations are initiated mainly by the state, their objectives and forms of functioning are dictated and strictly controlled by government bodies. These organizations are assigned the role of "the fifth wheel of the cart" in public administration. This model is mostly typical of societies with totalitarian form of government (for example, the Soviet Union).

In case of the second, liberal model intrusion and involvement of the state into the sphere of non-governmental organizations is undesirable and is minimized. Accountability of non-governmental organizations to the state is mostly reduced just as well. Relations between non-governmental organizations and the state are often conflicting; they appear "on opposing sides of the barricades" and perceive each other as predominantly undesirable rivals.

ganizations, faith-based organizations, professional associations, and foundations". See: http://web.worldbank.org/WBSITE/EXTERN AL/TOPICS/CSO/0,, contentMDK:20101499 menuPK:244752 pagePK:220503 piPK:2204 76 theSitePK:228717,00.html (Last visited on 13.12.2016.)

5 From the French word état-state. 
Those two models comprise some dangers from the position of balanced development of the social system. They can both hamper and restrain the development of nongovernmental organizations, and lead to social concussions.

The most preferable, namely for Armenia, and perspective type is the partnership model. This model is characterized by the principles of cooperation, mutual control and interpenetration. Civil organizations are more flexible in their activities; they can act as opponents, critics as well as supporters of the government held policy if that policy complies with their programs and aims. In this model most knowledgeable and experienced representatives of non-governmental organizations get more and more involved in various departments of state authorities and local selfgovernment, while representatives of state authorities participate in projects conducted by non-governmental organizations. The partnership model allows overcoming alienation, polarization and conflicting situations in relations between civil society organizations (SCOs) and the state, thus contributing to efficient dialogue and cooperation.

To develop the partnership model in Armenia, apart from educational and propaganda projects, some steps should be taken: 1) to increase effectiveness of financial support allocated from local funds to CSOs and 2) to form and work out mechanisms and culture for interaction between the state and CSOs.

Only few Armenian CSOs have paid staff $^{6}$. Most of these organizations conduct

6 According to 2010 survey these constitute 19,1\%: (CIVICUS Civil Society Index. Civil Society of Armenia...2010, p. 29). their projects via grants from foreign and international organizations.

Grants are allocated also from some local sources, namely from the state budget of RA. In 2012 AmD 7.4 billion was granted to local non-governmental organizations from the state budget. That sum was distributed among 115 organizations $^{7}$. It should be noted that $2 / 3$ of the sum - AmD 4.87 billion was given to merely 19 organizations.

The process of allocating grants to Armenian CSOs from the state budget is characterized by the lack of a systemized policy, definite and transparent procedures, little accessibility of information about the projects conducted and corruption risks.

To solve the problem effectively, "Civil Society Support National Foundation" (CSSNF) could be established, following the example of a number of western European countries $^{8}$. In result, the budget funds intended for CSOs as grants and donations will be allocated not to various bureaucracies, but will accumulate in the CSSNF.

The Foundation will, then process the offers and applications submitted by government bodies and CSOs, will examine them to reveal the array of issues for the solution of which involvement of CSOs is vital. Then, expertise will detect the degree of importance and urgency of those issues, relevant coefficient will be set to allocate the funds per year.

There are an array of issues beyond the interest realm of foreign and international do-

7 According to the Ministry of Justice, there were 3432 public organizations, 733 foundations and 301 legal entity unions registered in Armenia as of October 2012.

8 Such foundations function in Hungary, Croatia, Albany, Estonia, the Czech Republic. 
nor organizations, that are vital for the Armenian society. For instance, the issue of providing aid to military servicemen and their families, widows of fallen soldiers, their family members. CSOs could be especially efficient in the processes of monitoring projects conducted by government structures and in the fight against corruption.

Another means to improve the financial stability indicator of CSOs and to increase efficiency of the policy and projects conducted by government bodies is to form and develop the tradition of assigning certain projects in the spheres of social assistance, education and research, as well as some monitoring and control procedures over state-held programs to nongovernmental organizations on competitive basis.

Implementation of that model of social cooperation guarantees reduction in financial expenditure, meanwhile provides involvement of extra human, material and intellectual resources; public awareness about projects being implemented; definition of criteria to assess the quality of projects; extension of monitoring over partnership activity of state bodies and CSOs.

Fulfillment of the above described proposals will give the opportunity:

- To essentially improve the financial conditions of Armenian CSOs;

- To raise the credibility of state structures;

- To enhance state bodies-CSOs partnership and to improve mutual control processes;

- To increase engagement of CSOs in resolution of issues of public importance and to make it more effective;

- To decrease expenditure on issues of public importance;

- To avoid controlled and conflicting models of civil society, instead forming bases for the development of the more efficient model of civil society, that of partnership.

Regarding relations between political parties and CSOs, segmentational and linked models of civil society are identified.

In the first case, CSOs are classified according to social and political layers. They are classical in essence, are more often established by parties and act as their adjuncts. (See Diagram 2.) In that situation the social system is vulnerable against political conflicts and resonant reaction to the latter.

In the linked model CSOs seek objectives that unite citizens representing variable layers and having different political-ideological orientation. In the social system CSOs "are arranged vertically" to social and political layers. That arrangement promotes dialogue and partnership between different social classes, reconciles political organizations and reduces clashes, shapes relevant atmosphere for negotiations (Hovhannisyan, 2003, pp. 3435). This is a preferential model from the position of securing a cohesive and safe social system. 


\section{Diagram 2. Segmentational and Linked Models of Civil Society}

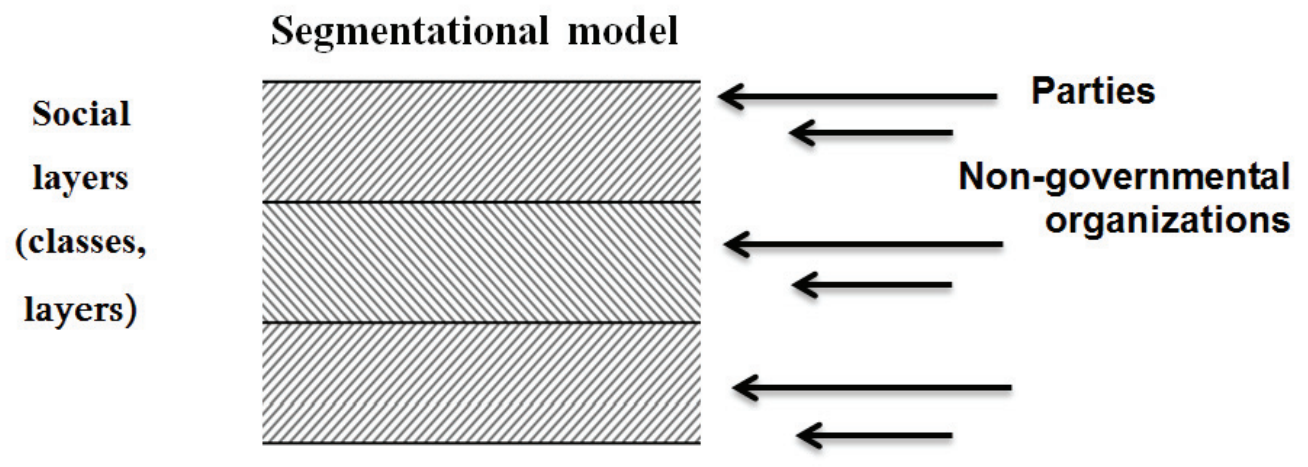

\section{Linked model}

\section{Social \\ layers \\ (classes, \\ layers)}

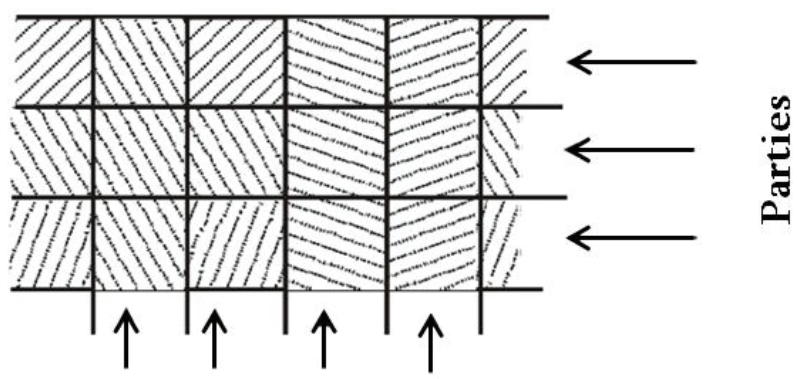

Non-governmental organizations

It is important that the state demonstrates care and consideration towards the formation of such non-governmental organizations that can promote cooperation between various social layers and overcoming social alienation between them.

In theoretical literature one may also come across some skeptical and critical views on civil society. While $18^{\text {th }}$ century French philosopher Jean-Jacques Rousseau found that a political-civil society is based on injustice, economic inequality and exploitative relations (Rousseau, 1762, p.15; Rousseau, 1761, p. 97), modern Indian researcher Jai Sen states that the civil society is a neocolonization project conducted by global elites in pursuing their interests (Sen, 2010). Persian theorist Mohammad Reza Nikfar notes that a civil society cannot be regarded an ideal one as it does not exclude misery, persecution and ignorance (Nikfar, 1999). However, it is important that the miserable and persecuted can unite in a civil society and fight for their rights and freedoms.

The existence of critical views can also be considered a positive phenomenon for the development, improvement, avoiding possible drawbacks.

\section{REFERENSES}

Aristotle's Politics (1877). Books I, III, IV, (VII) (with English trans. by W.E. Bolland). London, Longmans: Green and Co.,

https://archive.org/stream/cu3192407 1172914\#page/n121/mode/2up (Last visited on 19.12.2016.) 
Cicero, M.T. De Republica. Book I. http://www.thelatinlibrary.com/cicer o/repub1.shtml (Last visited on 06.12.2016.).

CIVICUS Civil Society Index. Armenian Civil Society: From Transition to Consolidation. Analytical Country Report. (2010). Yerevan.

Civil Society: history and possibilities. (2011). (Sudipta Khaviraj, \& Sunil Khilnani Eds.). Cambridge University Press.

Cohen, J.L., \& Arato, A. (1994). Civil Society and Political Theory. Massachusetts Institute of Technology Press, Chapter 2.

Hegel, G. (1991). Elements of the Philosophy of Right. Cambridge University Press.

Hobbes, Th. (1991). Leviafan ili materia, forma i vlast' gosudarstva cerkovnogo i grazhdanskogo. (Leviathan or The Matter, Forme and Power of a Common Wealth Ecclesiasticall and Civil, in Russian). Sochinenia v dvukh tomakh. T. 2. Moscow.

Hobbes, Th. (1998). On the Citizen. Cambridge University Press.

Hovhannisyan, H.O. (2003). Hasarakakan hamakargi zargacman himnaxndirnery'. (Issues of Social System Development, in Armenian). Yerevan.

Hovhannisyan, H.O. (2005). The Factor of Human Rights Protection as Criteria for the Development in the Social System. Armenia: A Human Rights
Perspective for Peace and Democracy. (pp. 23-30). Materials of Symposium. Potsdam.

Le Bon, G. (2005). The Crowd: A Study of the Popular Mind. Filicuarian Publishing Nikfar, M.R. (1999). Violence, Human Rights and Civil Society. Cologne. https://tavaana.org/en/content/moha mmad-reza-nikfar (Visited on 14.12.2016).

Rousseau, J.J. (1761). A Discourse upon the Origin and Foundation of the Inequality among Mankind. London: Pallmall.

https://archive.org/details/discourseu ponor00rous (Visited on 14.12. 2016).

Rousseau, J.J. (1762). The Social Contract or Principles of Political Right. Virgil, Eneid xi.

https://www.ucc.ie/archive/hdsp/Rou sseau_contrat-social.pdf (Visited on 14.12.2016).

Sen, J.(2010). Paper: Interrogating the Civil. Engaging Critically with the Reality and Concept of Civil Society. http://wiki.p2pfoundation.net/Engagi ng Critically with the Reality and Concept_of_Civil_Society (Visited on 14.12.2016).

Tocqueville, A. de $\left(1848^{\mathrm{a}}\right)$. De la démocratie en Amérique. Volume 1, Chap. 5 Pagnerre.

Tocqueville, A. de $\left(1848^{\mathrm{b}}\right)$. De la démocratie en Amérique. Volume 2, Chap. 5, Pagnerre. 